\title{
School-Related Variables as Correlates of Quality Leaning Outcome of Senior Secondary School Students
}

\author{
Michael O. Etan ${ }^{\mathrm{a}}$, Beauty U. Kenneth ${ }^{\mathrm{b}}$, Pius U. Angioha ${ }^{\mathrm{b},{ }^{*}}$, Thelma A. Abang ${ }^{\mathrm{b}}$, \& Depo Akande \\ ${ }^{a}$ Department of Environmental Education, University of Calabar, P.M.B. 1115, Calabar, Cross River state, Nigeria \\ ${ }^{b}$ Department of Sociology, University of Calabar, P.M.B. 1115, Calabar, Cross River state, Nigeria \\ ${ }^{c}$ Lead Financial \&Investment Corp, Somerset, United Kingdom
}

\begin{abstract}
This study attempts to examine the extent to which school-related variables such as teacher's quality, classroom ergonometric affects the Quality Leaning Outcome of senior secondary school students. The study was a survey research design. Data was collected from 385 senior secondary school students of government-operated secondary schools in Calabar, Cross River state, using a structured questionnaire. The purposive sampling technique was used in selecting the samples from the study area. Collected data were screened and checked for errors. The data was then analysed using descriptive and parametric statistics at 0.05 significant level. Out of the 385-instrument distributed, 376 was returned and used for analysis. From the interpreted data, the result revealed that high teacher quality statistically significantly differs from low teachers' quality in terms of Quality Leaning Outcome of secondary school students. This result is because the calculated t-value of $t(374)=3.57$ was higher than the critical $t-$ value of 1.96 at $\mathrm{p}<.05$. This result means that the high quality of teachers affects student academic outcome. Also, the result revealed that classroom ergonometric significantly relates to quality of academic outcome. Because the calculated $r$-value of $0.170^{*}$ is greater than the critical r-value of 0.098 at 0.05 level of significance with 374 degrees of freedom. With these results, we can conclude that school-related variables significantly relate to quality academic outcome. Hence, there is a need for improvement in school variables in schools in the study area.
\end{abstract}

Keywords: school-related variables, Quality Leaning Outcome, teacher's quality, classroom ergonometric.

\section{Introduction}

Education remains inextricably tied to the economic, political and social development of any society. It is not just crucial for socio-economic advancement. It is also vital to nurture progress in all spheres of human endeavour (Adeyemi, 2012). Education impacts skills and knowledge and creates human resources that drive economic development in all society. Formal education takes place in a structured school environment school provides a formal avenue through which human can achieve education. It is the formal environment through which an individual learner transforms from having potentials to acquiring skills that will fit meaningfully into the society that he belongs to (AjaOkorie, Odo \& Agwu, 2019). Hence, the practical learning process for school students is determined by a complex group of school variables and climate in Nigeria. Observation has revealed a drop in the standard of education, and many parents and guidance have lost confidence in the level of education. At the same time, many students who go through the school system do so smoothly. A lot equally find it difficult to go through school properly. Scholars assume the school climate and variable determines the performance of school student.

Moye (2014) assessed the effect of school variable on learning the outcome in schools. Adopting the descriptive research design, data were collected from 60 principals and 540 teachers randomly selected. Result revealed that a significant effect exists between school variables on quality education outcome Akpan (2020) examined the impact of school environment on the academic performance of biology student expose factor design was adopted in collecting data from 15 SS2 student findings revealed that class size, instructional facilities, school location on academic performance of sociology students. Expose factor design was adopted in collecting data from 150 SS2 students. Findings reveal that class, instructional facilities, school location on academic performance. Nsa, Offiong, Udo, and

* Corresponding author.

E-mail address: angiohapius@unical.edu.ng 
Ikot (2004) assessed the correlation between school variables and student academic outcome. Then survey design was adopted in collecting data from 300 students randomly selected from students. Data analysed revealed a significant relationship between school environment variables such as laboratory facilities and framing facilities on academic performance.

Daso (2013) assessed the relationship between school variables and students' academic performance in mathematics. Analysed data revealed a significant relationship between teachers' quality, academic climate, and student academic performance. In Calabar, the academic performance of students who attend government-owned school has become something of a worry for school administrators, academicians, and parents. This study examines how school-related variables such as teacher's quality and classroom ergonometric affect quality learning outcomes of senior secondary school students in Government Secondary schools in Calabar, Cross River State, Nigeria.

\subsection{The objective of the study}

The study's objective is to examine correlates between school-related variables and Quality Leaning Outcome of senior secondary school students. Specifically, the study;

(1) Examine the correlates between teacher's quality and Quality Leaning Outcome of senior secondary school students.

(2) Examine the extent to which classroom ergonometric relates to Quality Leaning Outcome of senior secondary school students.

\section{Materials and Methods}

\subsection{Design}

The survey research design was adopted for the study. The design allowed the researcher to study the population comfortably using a sample from the larger population, which can generalise the whole population. Data was collected using a structured questionnaire designed to make it easy for the sample under study to respond to them. The items contained 12 questions.

\subsection{Subjects}

385 samples were selected for the study. Seven government-owned secondary schools were purposively selected from Calabar: four (4) from Calabar South and Three (3) from Calabar Municipality to choose the sample. The schools selected are highlighted in table 1. From each school, 55 students were randomly selected from senior secondary school students (SS1 to SS3).

Table 1. Showing Subject selection

\begin{tabular}{|c|c|c|c|}
\hline $\mathbf{S} / \mathbf{N}$ & Local Govt. Area & Schools & Sample \\
\hline \multirow[t]{4}{*}{1.} & Calabar South & $\begin{array}{l}\text { Government Secondary School, Fenton } \\
\text { Street, Town }\end{array}$ & 55 \\
\hline & & $\begin{array}{l}\text { Email Secondary Community School, } \\
\text { Ekpo Eyo Street. }\end{array}$ & 55 \\
\hline & & $\begin{array}{l}\text { Government Secondary School, Mbukpa } \\
\text { Calabar }\end{array}$ & 55 \\
\hline & & Duke Town Secondary School & 55 \\
\hline \multirow[t]{4}{*}{2.} & Calabar Municipal & $\begin{array}{l}\text { Army Day Secondary School, Eburutu } \\
\text { Barracks. }\end{array}$ & 55 \\
\hline & & $\begin{array}{l}\text { Estate Secondary School, Calabar } \\
\text { Municipal. }\end{array}$ & 55 \\
\hline & & $\begin{array}{l}\text { Government Girls Secondary School Big } \\
\text { Qualified Town, Big Qua Town. }\end{array}$ & 55 \\
\hline & & Total & 385 \\
\hline
\end{tabular}




\subsection{Ethical Consideration}

Ethical approval was obtained from the sociology ethical committee board of the study to be carried out. A letter of approval was sent to 11 schools in Calabar, only 7 schools; three from Calabar Municipality and Four from Calabar South approval for the study to draw its participants from their school. The researcher also obtained verbal permission from the students used as subjects for the study. The students were assured of the anonymity of the information they supplied.

\subsection{Data Collection and Analysis Procedures}

Data collection was carried out within a three (3) months period, with five (5) research assistants drawn from various departments in the University. The research assistants were trained on the various methods of data collection. The researchers were with the research assistants divided into three groups of three each. Each group took care of two schools, with the lead researchers group taking care of three schools. Data collected from the subjects were checked for errors and then analysed using descriptive statistics before the result was then subjected to parametric statistics at 0.05 level of significance. Out of the 385 instruments distributed, only 376 was deemed correctly filled and used for analysis.

\section{Findings}

While submitting an article, authors will be asked to Transfer Intellectual Property Rights and Exploitation Rights.

\subsection{Objective one}

Objective one examines the correlates between teacher's quality and Quality Learning Outcome of senior secondary school students. Elicited data from subjects under study were analysed using descriptive statistics such as Table, graph, frequency distribution and percentages. The result is presented in table 2 to 4 , then figure 1 to 3

Table 2. Subject response on best 6 subjected teachers $(\mathrm{N}=376)$

\begin{tabular}{lll}
\hline 6 Best Subject Teachers & Frequency & Percentage (\%) \\
\hline Mathematics & 9 & 2.39 \\
English & 127 & 33.78 \\
Biology & 19 & 5.05 \\
Economics & 84 & 22.34 \\
Civic Education & 87 & 23.19 \\
Tourism & 51 & 13.56 \\
\hline Total & $\mathbf{3 7 6}$ & $\mathbf{1 0 0 . 0}$ \\
\hline
\end{tabular}

Field survey, 2021

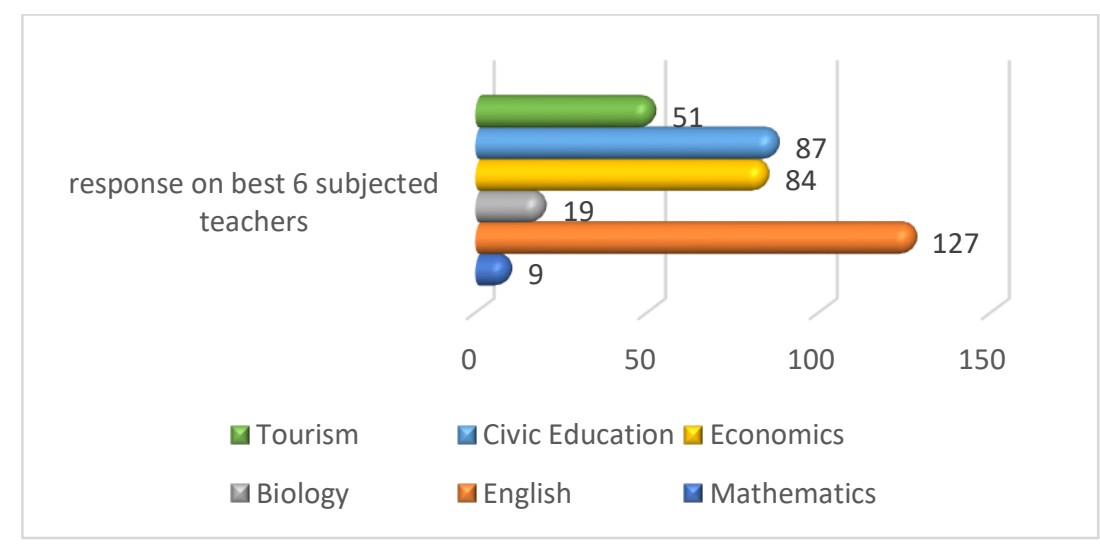

Figure 1. Response on teacher's quality 
Table 3. Response on Teachers quality

\begin{tabular}{lllll}
\hline S/N & Questions & True & Not True & I don't know \\
\hline 2 & You enjoy the way teachers teach you & $184(48.94)$ & $158(42.02)$ & $34(9.04)$ \\
3 & All your major subject teachers are outstanding & $191(50.80)$ & $122(32.45)$ & $63(16.76)$ \\
4. & The way the teachers teach you will determine your & $368(97.87)$ & 0 & $8(2.13)$ \\
& understanding of any subject & & &
\end{tabular}

Source: Field survey, 2021

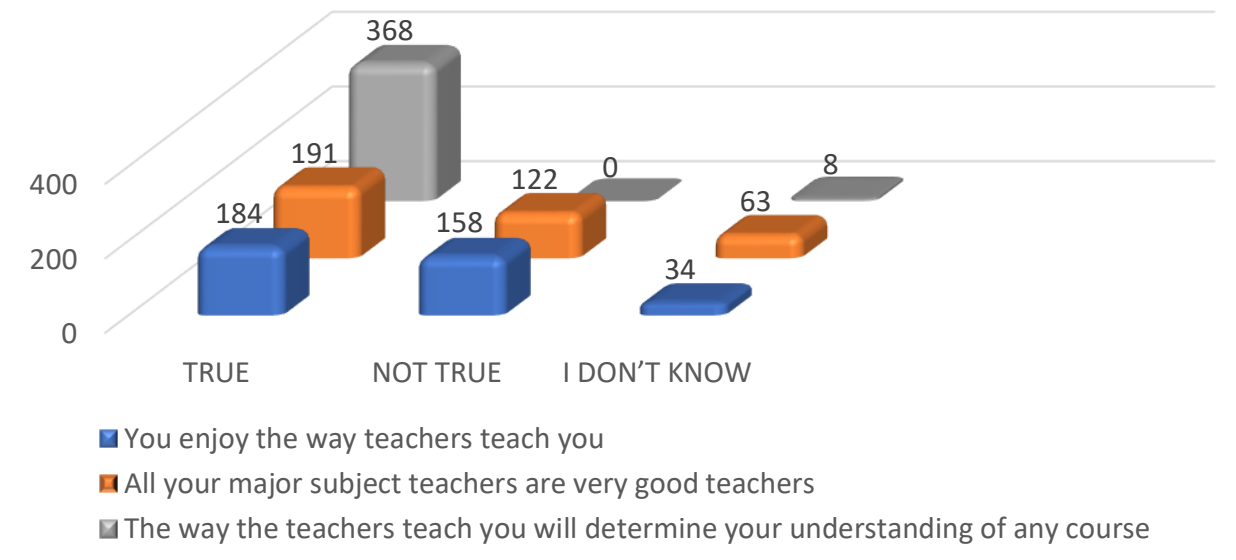

Figure 2. Response on teacher's quality

Table 4. Subject response on which of the subject teacher should be changed $(\mathrm{N}=376)$

\begin{tabular}{lll}
\hline Subject teacher to be changed & Frequency & Percentage (\%) \\
\hline Mathematics & 126 & 33.51 \\
English & 18 & 4.79 \\
Biology & 96 & 25.53 \\
Economics & 78 & 20.74 \\
Civic Education & 15 & 3.99 \\
Tourism & 3 & 11.43 \\
\hline Total & $\mathbf{4 1 2}$ & $\mathbf{1 0 0 . 0}$ \\
\hline
\end{tabular}

Source: Field survey, 2021

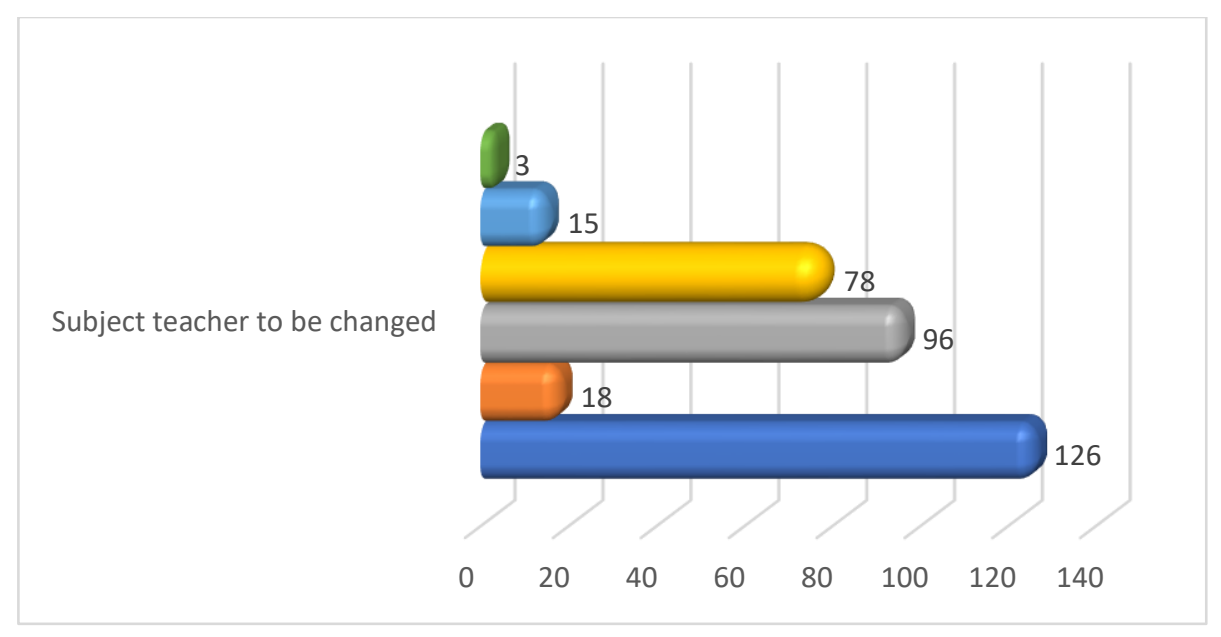

Figure 3. Response on teacher's quality 
Respondent response on teacher's quality shows that 127 respondents representing 33.78 per cent reported that their best teacher is the English teacher, followed by 87 respondents representing 23.19 per cent who reported civic education. 84 respondents representing 22.34 per cent, reported economics teacher was their best subject teacher, 51 respondents representing 13.56 per cent, reported that tourism teacher was their best subject teacher. 19 respondents representing 5.05 reported that biology teacher was their best subject teacher, and only 9 respondents representing 2.39 per cent reported mathematics as their best subject teacher. When asked if the respondents enjoyed the way teachers teach them, 184(48.94\%) respondents reported accurate, $158(42.02 \%)$ respondents reported Not true, and 34 (9.04\%) respondents reported I don't know. On all the significant subjects' teachers are very good; 191 (50.80\%) respondents reported True, 122(32.45\%) respondents reported Not accurate, and 63(16.76\%) respondents reported I don't know. On the way the teacher teaches them determines their understanding of any subject, 368.

To check the extent to which teacher's quality affects the quality of academic outcome. Independent T-Test was used to analyse the data at 0.05 confidence level.

Table 5. Independent T-Test for teacher's quality affects Quality Learning Outcome

\begin{tabular}{lllllll}
\hline Grouping variable & N & Df & Mean & SD & t-value & Sig. \\
\hline High teacher's quality & 227 & 374 & 14.11 & 6.10 & 3.57 & .000 \\
Low teacher's quality & 149 & & 11.93 & 4.00 & & \\
\hline
\end{tabular}

* significant at $0.05 ; \mathrm{df}=374 ;$ critical t-value 1.96

Source: Field survey, 2021

The analysis revealed that high teacher quality statistically significantly differs from low teachers quality in terms of Quality Leaning Outcome of secondary school students. This result is because the calculated t-value of $t(374)=3.57$ was higher than the critical $\mathrm{t}$-value of 1.96 at $\mathrm{p}<.05$. This result means that the high quality of teachers affects student academic outcome.

Also, the result revealed that, out of the 376 respondents used for the, 227 representing $61.6 \%$ believe they have highquality teachers, while only 149 , representing $38.3 \%$, think they've low-quality teachers. On average, high-quality teachers have a higher mean value $(\mathrm{M}=14.11, \mathrm{SD}=6.10)$, which is an indicator of quality learning outcome than low teacher quality $(\mathrm{M}=11.93$; $\mathrm{SD}=4.00)$. However, the effect size was moderate, revealing that this finding was substantial in real terms since $r=(0.41)$, which is a measure of effect size indicates the proportion of explained variance on the dependent variable, which implies that $41 \%$ of student Quality Learning Outcome is accounted for by teacher's quality. This result implies that teacher's quality significantly affects the quality of learning outcome.

\subsection{Objective Two}

Objective two examines the extent to which classroom ergonometric relates to Quality Leaning Outcome of senior secondary school students. Elicited data from subjects under study were analysed using descriptive statistics such as Table, graph, frequency distribution and percentages. Result is presented in table 5, then figure 1 to 3

Table 6. Respondents response on Classroom Ergonometric and quality of learning outcome

\begin{tabular}{llccc}
\hline S/N & Question & Yes & No & Not Sure \\
\hline 1. & My classroom is comfortable & 230 & 144 & $2(0.53 \%)$ \\
& & $(61.17 \%)$ & $(38.30 \%)$ & 14 \\
2. & The chairs and tables in my classroom are enough for my & 216 & 146 & 14 \\
& classmates and me & $(57.45 \%)$ & $(38.83 \%)$ & $(3.72 \%)$ \\
3 & I have a very comfortable seat and Table in my classroom & 193 & 183 & 0 \\
& & $(51.33 \%)$ & $(48.67 \%)$ & \\
4 & There is enough ventilation in my classroom & 285 & 82 & 9 \\
& & $(75.80 \%)$ & $(21.81 \%)$ & $(2.39 \%)$ \\
5 & Your classroom is designed in a way that you can see and & 214 & 137 & 25 \\
& hear the teacher when they teach & $(56.91 \%)$ & $(36.44 \%)$ & $(6.65 \%)$ \\
6 & There is no fan in your classroom. Even if there is, it is not & 321 & $55(14.62)$ & 0 \\
& working & $(85.37 \%)$ & & 31 \\
7. & 0 & 345 & $31.76 \%)$ & $(8.24 \%)$ \\
\hline
\end{tabular}




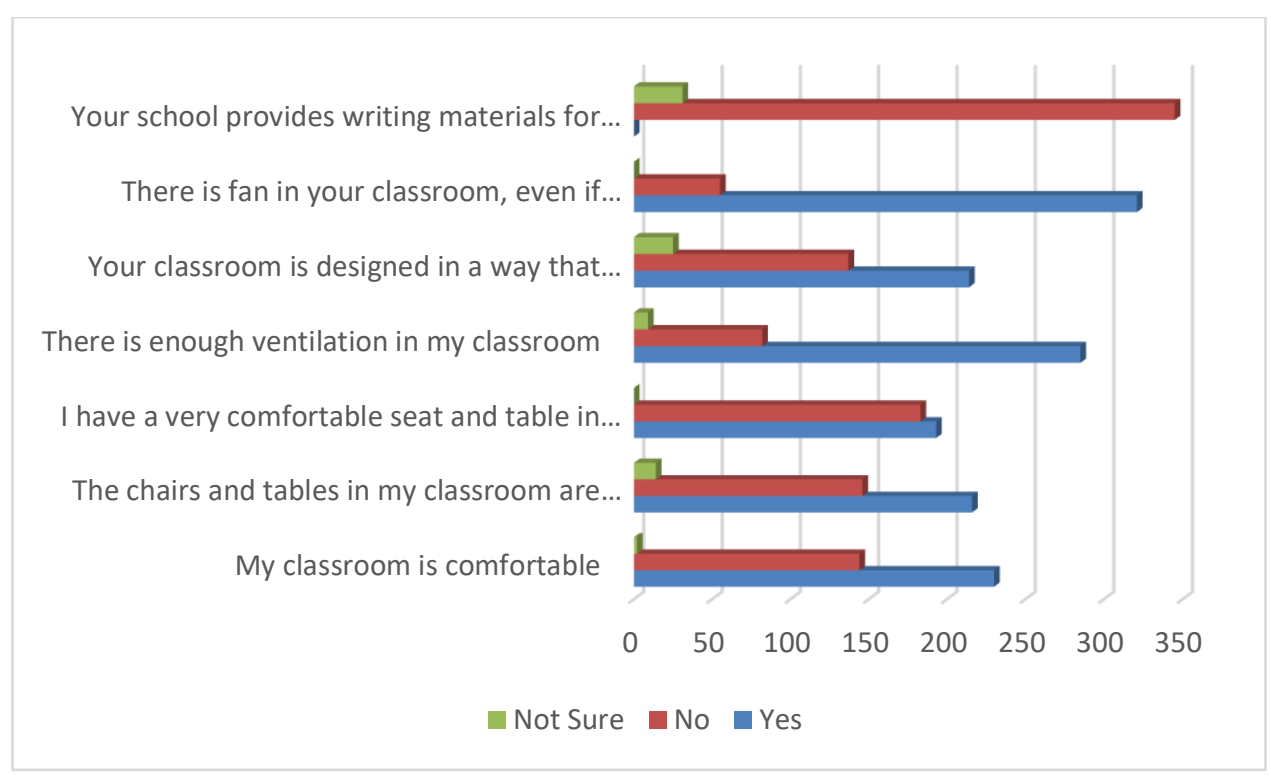

Figure 4. Response on Classroom Ergonometric

Respondents' response on classroom ergonometric revealed that on my classroom is comfortable. 230 respondents representing 57.45 per cent reported Yes, 144 respondents representing 38.30 per cent reported No and 2 respondents representing 0.53 per cent reported Not sure. 216 respondents representing 57.45 per cent report Yes, 146 respondents representing 38.83 per cent reported No and 14 respondents representing 3.72 per cent reported Not that the chairs in the classrooms are enough for them and their classmates. 193 respondents representing 51.33 per cent reported Yes, 138 respondents representing 48.67 per cent reported No that they have a very comfortable seat and tables in their classroom. 285 respondents representing 75.80 per cent reported Yes, 82 respondents representing 21.8 per cent reported No and 9 representing 2.39 per cent reported Not sure that there is enough ventilation in their classroom. 214 respondents representing 56.91 per cent reported Yes, 137 respondents representing 36.44 per cent reported N0 and 25 representing 6.65 per cent reported that their classroom is designed to see and hear the teachers when they teach. 321 respondents representing 85.37 per cent reported Yes, 55 respondents representing 14.62 per cent reported No that there is no fan in their classroom, and it is not working even when there is. 345 respondents representing 91.76 per cent report No and 31 respondents representing 8.31 per cent reported Not sure that the school provides writing materials for use.

To check the extent to which classroom ergonometric relates to quality of academic outcome. Pearson product Moment Correlation was used to analyse the result at 0.05 confidence level.

Table 7. Pearson product-moment correlation coefficient analysis for classroom ergonometric relates with quality of academic outcome. $(\mathrm{N}=374)$

\begin{tabular}{llllll}
\hline Variable & $\mathbf{N}$ & Mean & SD & r-value & Sig. \\
\hline Classroom Ergonometric & 374 & 9.66 & 2.32 & $0.170^{* *}$ & .002 \\
Quality of academic outcome & 374 & 13.28 & 5.49 & & \\
\hline
\end{tabular}

*significant at 0.05 level; $d f=372$ critical $r$ value $=0.098$

Source: Field survey, 2021

The result in Table 7 revealed that the calculated r-value of $0.170 *$ is greater than the critical r-value of 0.098 at 0.05 level of significance with 374 degrees of freedom. By this result, classroom ergonometric significantly relates to quality of academic outcome. The squared correlation $(0.170)^{2}$, a measure of effect size, indicates the proportion of explained variance on the dependent variable. Therefore, only $2 \%$ of the variance in quality of the academic outcome. Though the magnitude of the effect is small, if the classroom ergonometric of schools is improved, the quality of 
academic outcome will improve. Therefore, we can conclude that classroom ergonometric significantly relates to quality of academic outcome.

\section{Discussion of Findings}

From the analysis of the data analysed on the first objective using descriptive statistics, the result revealed that most of the students, $33.78 \%$ in the study area, prefers their English teachers. This is followed by civic education (23.19\%) and then economic teacher (22.54\%), the least most liked teacher is the mathematics teacher with only 2.39 per cent seeing their mathematics teacher as their best. On the general question raised, only 48.94 per cent of the student enjoys the ways their teachers teach them, with just 50.80 per cent of the student agreeing that their major teachers are good. 97.87 per cent of the students agreed that the way they are taught determines their learning outcome. 33.51 per cent of the students reported their mathematics teacher should be changed, 25.53 per cent reported their biology teacher should be changed, with only 4.79 per cent wanting their English teacher changed.

The result from the descriptive statistics subjected to parametric statistics using independent T-test at 0.05 confidence level. Result revealed that analysis revealed that high teacher quality statistically significantly differs from low teachers' quality in terms of Quality Leaning Outcome of secondary school students. This result is because the calculated $\mathrm{t}$-value of $\mathrm{t}(374)=3.57$ was higher than the critical $\mathrm{t}$-value of 1.96 at $\mathrm{p}<.05$. This result means that the high quality of teachers affects student academic outcome. Also, high-quality teacher has a higher mean value $(\mathrm{M}=$ $14.11, \mathrm{SD}=6.10)$ which is an indicator of Quality Leaning Outcome than a low teacher quality $(\mathrm{M}=11.93 ; \mathrm{SD}=$ 4.00). However, the effect size was moderate, revealing that this finding was substantial in real terms since $r=(0.41)$, which is a measure of effect size indicates the proportion of explained variance on the dependent variable, which implies that $41 \%$ of student Quality Learning Outcome is accounted for by teacher's quality. This result implies that teacher's quality significantly affects the quality of learning outcome.

This finding is corroborated by studies such as that of Darling -Hammond (2000), who found that policy investment in the teacher's quality significantly relates to student performance. Oni (2004) found a significant correlation between teacher's quality and academic achievement. Ali, Tela and Saleh (2020), in their study on teacher's quality and academic performance of students in public senior secondary school in Maiduguri, found that teacher's qualification, experience significantly relate to student's performance.

From the analysis of the second objective, the result revealed that a large percentage of students $(61.17 \%)$ believe that their classroom is comfortable. 57.47 per cent of the student reported that their classroom has enough seats and tables for the students, with a large amount of the student $(75.80 \%)$ opined that their classroom has enough ventilation 56.91 per cent of the students maintain that the way their classroom is designed they can see and hear their teacher teach them. From data collected, none of the school provides writing materials for their students.

The descriptive analysis was subjected to parametric statistics using person product-moment correlation at 0.05 confidence level. Result revealed that the calculated $\mathrm{r}$-value of $0.170 *$ is greater than the critical $\mathrm{r}$-value of 0.098 at 0.05 level of significance with 374 degrees of freedom. Also, only $2 \%$ of the variance in quality of academic outcome. Though the magnitude of the effect is small, if the classroom ergonometric of schools is improved, the quality of academic outcome will improve. Therefore, we can conclude that classroom ergonometric significantly relates to quality of academic outcome. This finding is similar to that of Ezike (2018) found that classroom environment significantly relates to academic performance. Ekpo, Akpan, Essien and Ima-Obot (2009) found that classroom climates affect students' academic performance.

\section{Conclusion and Recommendation}

The result from data gathered to check the impact of school-related variables and quality of academic outcome. The analysis revealed a significant correlation between teacher's quality, classroom ergonometric and student learning outcome. Hence there is a need for improvement in the school environment climate, especially classroom designs and its atmosphere. The appropriate authorities in charge of education at both state and national level should recognise the importance of teachers in the society. Hence recruitment into teaching positions should be on merit and for those with the qualification. Also, those who are to be given any role in government, such as that of minister for education or commissioner for education, should have had classroom experience. 


\section{References}

Adeyemi, T. O. (2012). School Variables and Internal Efficiency of Secondary Schools in Ondo State, Nigeria. Journal of Educational and Social Research,2(3), 205. https://www.richtmann.org/journal/index.php/jesr/article/view/11883

Aja-Okorie, U., Odo, J., \& Agwu, L.O. (2019). School-Related Variables and Students' Academic Performance in Secondary School in Abakaliki Education Zone of Ebonyi State, Nigeria. IOSR Journal of Research \& Method in Education 9, (5), PP 08-15

Ali, M., Tela, M. G., \& Saleh, B. (2020). Impact of Teacher's Quality on Students' Academic Performance in Public Senior Secondary Schools in Maiduguri Metropolis, Borno State, Nigeria. Asian Journal of Education and Social Studies, 18-24. https://doi.org/10.9734/ajess/2020/v11i330292

Darling-Hammond, L. (2000). Teacher Quality and Student Achievement. Education Policy Analysis Archives, 8, 1. https://doi.org/10.14507/epaa.v8n1.2000

Daso, P. O. (2013). Science education reforms in Nigeria: Implication for science teachers. Global Advanced Research Journal of Peace, Gender and Development Studies, 2(5), 86-90

Ekpo, K., Akpan, O., Essien, E., \& Imo-Obot, M. (2009). Classroom Climate and Students’ Academic Achievement in Social Studies in Cross River, Nigeria. African Research Review, 3(4), $412-428$. https://doi.org/10.4314/afrrev.v3i4.47576

Ezike, B. U. (2018). Classroom environment and academic interest as correlates of achievement in senior secondary school chemistry in Ibadan South West local government area, Oyo State, Nigeria. Global Journal of Educational Research, 17(1), 61. https://doi.org/10.4314/gjedr.v17i1.9

Moye G. P (2014). Effects of school variables on the Assurance of Quality Learning Outcomes in schools, International Journal of Learning Teaching and Educational Research; vol. 9 No 1 December 2014

Moye, G. P. (2014). Effects of School Variables on the Assurance of Quality Learning Outcomes in Schools. International Journal of Learning, Teaching and Educational Research, 9, (1), pp. 117-131,

Nsa, S. O., Offiong, A. A., Udo, M. F., \& Ikot, A. S. (2014). School Environmental variables and students' academic performance in Agricultural Science. International Journal of Business and Social Science, 5(1).

Oni, J. O. (2014). Teacher Quality and Student Academic Achievement in Basic Technology in Junior Secondary Schools in South-West, Nigeria. Journal of Educational and Social Research, 4(3), 397-402. https://doi.org/10.5901/jesr.2014.v4n3p397

Sakiz, G. (2015). Perceived teacher factors in relation to students' achievement-related outcomes in science classrooms in elementary school. European Journal of Science and Mathematics Education, 3(2), 115-129. https://doi.org/10.30935/scimath/9426 